\title{
Interleukin-12 family cytokines and sarcoidosis
}

\author{
Sabine Ringkowski ${ }^{1,2,3}$, Paul S. Thomas ${ }^{1,2}{ }^{*}$ and Cristan Herbert ${ }^{1}$ \\ 1 Inflammation and Infection Research Centre, Faculty of Medicine, University of New South Wales, Sydney, NSW, Australia \\ ${ }^{2}$ Respiratory Medicine Department, Prince of Wales Hospital, Sydney, NSW, Australia \\ ${ }^{3}$ Faculty of Medicine, University of Heidelberg, Heidelberg, Germany
}

Edited by:

Stelios Loukides, University of Athens Medical School, Greece

\section{Reviewed by:}

Jutaro Fukumoto, University of South Florida, USA

Effrosyni D. Manali, National and Kapodistrian University of Athens, Greece

\section{${ }^{*}$ Correspondence:}

Paul S. Thomas, Respiratory Medicine Department, Prince of Wales Hospital, Level 2 Dickinson Building via High Street, Barker Street, Randwick, Sydney, NSW 2031, Australia e-mail:paul.thomas@unsw.edu.au
Sarcoidosis is a systemic granulomatous disease predominantly affecting the lungs. It is believed to be caused by exposure to pathogenic antigens in genetically susceptible individuals but the causative antigen has not been identified. The formation of non-caseating granulomas at sites of ongoing inflammation is the key feature of the disease. Other aspects of the pathogenesis are peripheral T-cell anergy and disease progression to fibrosis. Many Tcell-associated cytokines have been implicated in the immunopathogenesis of sarcoidosis, but it is becoming apparent that IL-12 cytokine family members including IL-12, IL-23, IL27 , and IL-35 are also involved. Although the members of this unique cytokine family are heterodimers of similar subunits, their biological functions are very diverse. Whilst IL-23 and IL-12 are pro-inflammatory regulators of Th1 and Th17 responses, IL-27 is bidirectional for inflammation and the most recent family member IL-35 is inhibitory. This review will discuss the current understanding of etiology and immunopathogenesis of sarcoidosis with a specific focus on the bidirectional impact of IL-12 family cytokines on the pathogenesis of sarcoidosis.

Keywords: sarcoidosis, IL-12, IL-23, IL-27, IL-35, pathogenesis, granuloma, anergy

\section{INTRODUCTION}

The term sarcoidosis was first used in 1899 to describe pathological features of skin lesions, but is currently used to describe a systemic granulomatous inflammatory disease predominantly affecting the lungs (Boeck, 1899; Müller-Quernheim et al., 2012). The non-caseating granulomas observed in affected tissues remain its key pathological feature (Heinle and Chang, 2014). More than 100 years of research have been unable to reveal the etiology and pathogenesis of the disease.

Current investigations into the pathogenesis include studies of gene polymorphisms and the role of possible infective and non-infective antigens (Adrianto etal., 2012; Negi et al., 2012; Dubaniewicz et al., 2013). Important questions that remain unexplained are how and why granulomas are formed and why approximately $20 \%$ of all patients develop pulmonary fibrosis whereas the majority experience remission (Iannuzzi and Fontana, 2011; Müller-Quernheim et al., 2012; Broos et al., 2013; Loke et al., 2013). Also yet to be explained is the observed anergy of peripheral T-cells in affected patients (Lee et al., 2011).

The IL-12 family of cytokines, (IL-12, IL-23, IL-27, and IL-35), have been implicated in other granulomatous inflammatory diseases such as tuberculosis and Crohn's disease, and a role for some of these cytokines has also been proposed in sarcoidosis (Larousserie et al., 2004; Mroz et al., 2008; Judson et al., 2012). Thus the purpose of this review is to discuss the current understanding of the etiology and pathogenesis of sarcoidosis with a focus on a possible role for the IL-12 family cytokines.

\section{EPIDEMIOLOGY}

The incidence and prevalence of sarcoidosis varies between different ethnic groups. Sarcoidosis is more common in females and peak incidence is between 30-50 years (Rybicki and Iannuzzi, 2007). African Americans and Northern Europeans have the highest incidence rate ranging between 15-80/100.000 (Rybicki and Iannuzzi, 2007). Interestingly more recent studies in different countries all reveal an increased prevalence and incidence compared to former reports, indicating that sarcoidosis might be more common than previously thought (Deubelbeiss et al., 2010; Nicholson et al., 2010; Erdal et al., 2012).

\section{ETIOLOGY}

Sarcoidosis is believed to be caused by exposure to antigens and environmental agents in genetically susceptible individuals (Eishi, 2013).

The ACCESS study (A case control etiologic study of sarcoidosis) identified exposure to insecticides as well as mold, mildew, and musty odors as risk factors pointing towards a role of microbial bioaerosols in the pathogenesis of sarcoidosis (Newman et al., 2004). The same study confirmed a significantly higher risk for first and second degree relatives of affected patients to be diagnosed with sarcoidosis suggesting an involvement of genetic factors (Rybicki et al., 2001).

\section{POTENTIAL ANTIGENS}

Several observations support the idea of microbial antigens playing a role in the pathogenesis of sarcoidosis. Early studies found that tissue samples from sarcoid patients injected into animals caused granuloma formation (Iwai and Takahashi, 1976; Mitchell et al., 1976). However when similar samples are disinfected they do not cause granuloma formation, suggesting a cell-mediated or microbial origin (Ikonomopoulos et al., 2000, 2006). Similarly several case reports indicate that sarcoidosis might be transmittable via organ transplantations (Burke et al., 1990; Heyll et al., 
1994; Padilla et al., 2002; Pukiat et al., 2011; Das et al., 2012). Likewise, there are reports of both successful antibiotic and antifungal treatment of sarcoidosis perhaps related to the potential sarcoid antigens, Mycobacterium tuberculosis, Propionibacterium acnes, and more recently, fungi (Terčelj et al., 2007, 2011a; Drake et al., 2013; Takemori et al., 2014).

As sarcoidosis is a granulomatous disease, M. tuberculosis has long been suspected to be involved, yet the bacterium has never been isolated from sarcoid tissue (Milman et al., 2004). Nonetheless newer methods of detection have revealed that M. tuberculosis antigens are present in sarcoid lesions (Gupta et al., 2007; OswaldRichter et al., 2012). Peripheral blood mononuclear cells (PBMCs) as well as bronchoalveolar lavage fluid (BAL) cells show hypersensitivity when stimulated with those antigens, producing higher amounts of interferon gamma (IFNy) than healthy controls without Bacillus Calmette-Guerin vaccination (Oswald-Richter et al., 2009, 2012; Ahmadzai et al., 2012).

Similarly, $P$. acnes antigens cause hypersensitivity in only a subgroup of patients but the bacterium is detected in and isolated from sarcoid lymph nodes and tissue more frequently than in healthy controls (Furusawa et al., 2012; Negi et al., 2012).

Fungal exposure is another risk factor for sarcoidosis and higher levels of beta-glucan (a fungal cell wall component) have been found in BAL fluid of patients compared to controls suggesting a possible role for fungal antigens in sarcoidosis (Newman et al., 2004; Terčelj et al., 2011b, 2013).

Despite the evidence for involvement of both M. tuberculosis antigens and $P$. acnes as well as fungal exposure in the pathogenesis of sarcoidosis, these organisms only amount for a subgroup of patients leaving room for other theories that suggest a role for non-microbial antigen such as autoantigens, serum amyloid $\mathrm{A}$, and human heat shock proteins (Salazar et al., 2000; Wahlstrom et al., 2007, 2009; Chen et al., 2010; Bargagli et al., 2011; Dubaniewicz, 2013; Zhang et al., 2013).

\section{GENE POLYMORPHISMS}

Just as there is probably no single "sarcoid antigen," there is no single "sarcoidosis gene." Multiple gene polymorphisms associated with sarcoidosis have been identified in different regional subgroups but many of the results can not be reproduced in different cohorts (Spagnolo and Grunewald, 2013). Human leucocyte antigen (HLA) polymorphisms have received the most attention with the hypothesis that sarcoidosis might be an antigen driven disease. Whilst HLA-DRB1*03 is associated with an increased risk for Löfgren's syndrome, HLA-DRB1*07, *11, *14, and ${ }^{*} 15$ are related to chronic disease while HLA*DRB* 01 and *13 seem to be protective (Grunewald etal., 2010; Sato et al., 2010; Wijnen et al., 2010; Grubic et al., 2011; Zhou et al., 2011; Wennerstrom et al., 2012). Only two non-HLA polymorphisms have been confirmed: annexin A11 being protective whereas a butyrophilin-like 2 polymorphism is associated with chronic disease (Spagnolo et al., 2007; Milman et al., 2011; Wijnen et al., 2011; Adrianto et al., 2012; Morais et al., 2012; Suzuki et al., 2012). More recently, genome-wide association studies and single polymorphism analyses have also suggested a role for toll-like receptors, the myeloid differentiation primary response gene (Judson et al., 2012), IL-23 receptor (IL-23R), TNF- $\alpha$, IL-10, NOTCH4, and
OS9 polymorphisms (Veltkamp et al., 2007; Vasakova et al., 2010; Kim et al., 2011; Adrianto et al., 2012; Daniil et al., 2013; Hofmann etal., 2013; Song etal., 2014; Wijnen etal., 2014). As yet, none of these findings have been shown to have external validity and their potential clinical significance and contribution to the pathogenesis remain to be determined. Thus the literature shows the concept of sarcoidosis being an antigendriven immunoreaction in genetically susceptible individuals to be accurate in principle but lacking in specificity in all patient groups.

\section{PATHOGENESIS INITIATION, ACCUMULATION, AND EFFECTOR PHASE}

Sarcoidosis is characterized by non-caseating granulomas that typically consist of a core of Th1 cells and activated macrophages surrounded by B-cells, fibroblasts and CD8 lymphocytes as well as Th17 cells, and Treg cells (Miyara et al., 2006; Iannuzzi and Fontana, 2011; Ten Berge et al., 2012). Granuloma formation can be explained in four stages: initiation, accumulation, effector phase, resolution/development of fibrosis. It has traditionally been explained by antigen-driven Th1 responses and interactions between antigen presenting cells (APC) and Th1 cells but recent advances have implicated Th17 in the process of granuloma formation as well (Figure 1; Co et al., 2004; Chen and Moller, 2011; Iannuzzi and Fontana, 2011; Müller-Quernheim et al., 2012; Broos et al., 2013).

Th1 cell accumulation in the lungs is characteristic of sarcoidosis and these cells spontaneously produce increased amounts of IL-2 and IFN $\gamma$ in the BAL fluid (Robinson et al., 1985; Moseley et al., 1986; Prasse et al., 2000). The development of these Th1 cells depends on IL-12 and IL-18, both of which are elevated in the BAL fluid of sarcoidosis patients supporting a Th1-based hypothesis of granuloma formation (Stoll et al., 1998; Yoshimoto et al., 1998; Shigehara et al., 2001; Mroz et al., 2008).

Increased numbers of Th17 cells in BAL, blood and granulomatous tissue of sarcoidosis patients suggest a contribution of these cells in the pathogenesis of sarcoidosis (Facco et al., 2011; Ten Berge et al., 2012; Richmond et al., 2013). Th17 cells are a subset of pro-inflammatory CD4+ cells that are associated with autoimmunity and antimicrobial defense (Bedoya et al., 2013). They develop from naïve CD4+ T-cells in the presence of TGF $\beta$, IL-1 $\beta$, IL-6, and IL-23 (Acosta-Rodriguez et al., 2007; Wilson et al., 2007; Manel etal., 2008; Volpe et al., 2008). In patients with sarcoidosis IL-1 $\beta$, IL-6, and TGF $\beta$ are elevated in the BAL fluid compared to healthy controls and IL-23 has been detected in granulomas creating a Th17 supportive microenvironment (Zissel et al., 1996; Idali et al., 2006; Judson et al., 2012; Urbankowski et al., 2012). A few studies have analyzed the role of the Th17 effector cytokines IL-17A/F, IL-21, and IL-22 in sarcoidosis, but the results are contradictory. One group demonstrated that sarcoid Th17 cells produce more IL-17A compared to healthy controls, whereas others demonstrated that IL-17 was downregulated after stimulation with $P$. acnes (Furusawa et al., 2012; Richmond etal., 2013). In skin lesions of sarcoidosis patients, IL-21 has been found to be elevated, whereas IL-17 and IL22 were not dysregulated (Judson et al., 2012). Thus there is some evidence for a role of Th17 cells in granuloma formation 


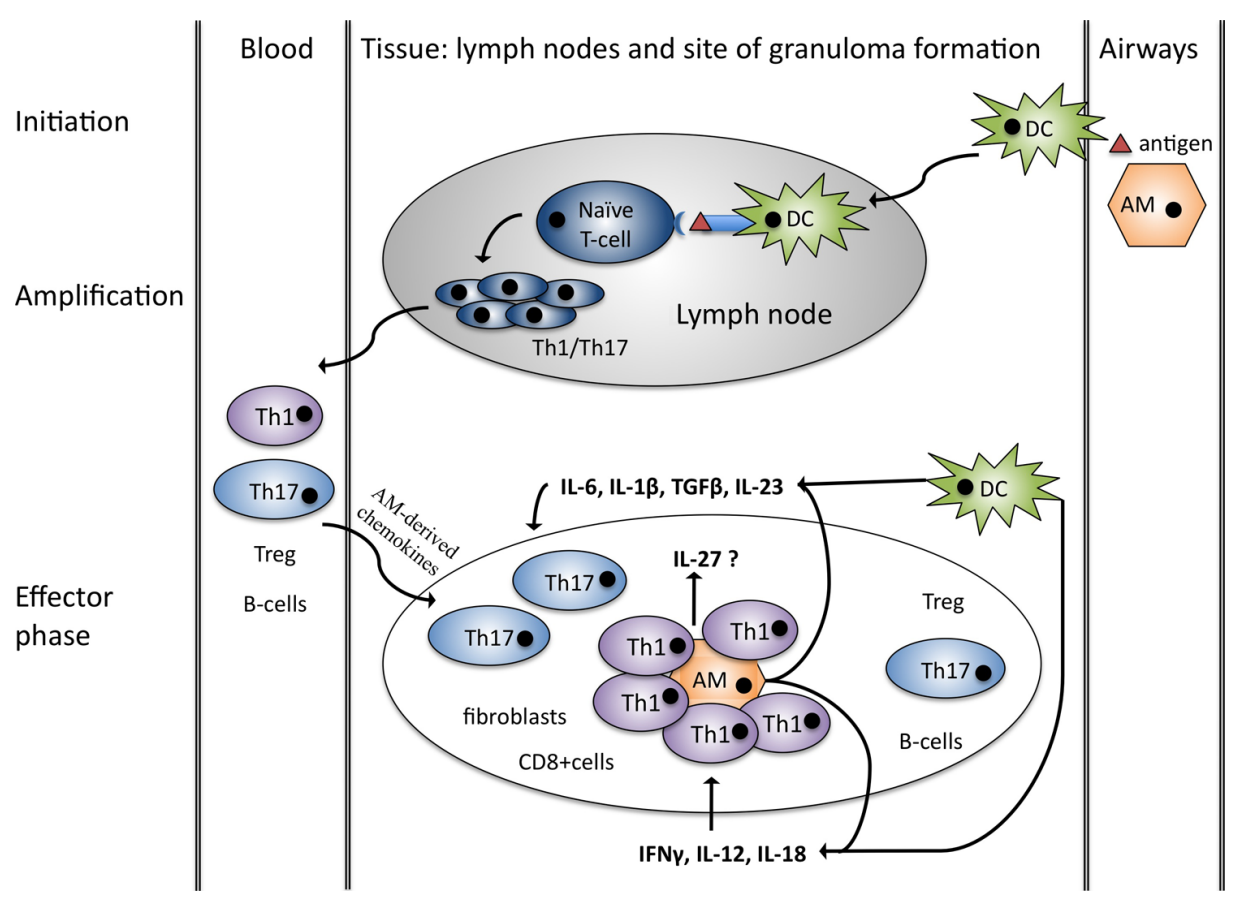

FIGURE 1 | Granuloma formation -Th1/Th17 hypothesis. Initiation: alveolar macrophages (AM) and dendritic cells (DC) are activated by a putative antigen. DC migrates to lymph nodes and initiates Th1/Th17 cell amplification. Chemokines produced by alveolar macrophages attract Th1/17,
Treg, B-cells as well as CD8+ cells and fibroblast and initiate granuloma formation (effector phase). Both DC and macrophages produce cytokines favoring Th1 and Th17 cells in sarcoidosis. Figure adopted from Broos et al. (2013). but more studies are needed to define the role of Th17 effector cytokines.

\section{RESOLUTION VERSUS FIBROSIS}

The factors determining the clinical course of sarcoidosis, either granuloma resolution or progression to fibrosis, remain unclear (Patterson et al., 2012). On a cellular level remission is believed to occur through antigen clearance through a strong Th1 response and recovery of regulatory T-cells (Treg; Müller-Quernheim et al., 2012; Oswald-Richter etal., 2013). There is evidence supporting the theory that fibrosis is caused by a switch from Th1 responses towards Th2 (Iannuzzi et al., 2007; Müller-Quernheim et al., 2012). In line with this hypothesis, the concentration of the Th2 cytokine IL-5 is lower in those without fibrosis compared to those with fibrotic disease (Patterson et al., 2013). Further support for a switch to Th2 responses is provided by several studies that identified a Th2 driven immunosuppressive polarization of alveolar macrophages (AM) in fibrotic patients although these findings remain controversial (Prasse et al., 2006; Wikén et al., 2010; Prokop et al., 2011). Thus there is some evidence suggesting a contribution of Th2 responses to the development of fibrosis but further studies are required to confirm this theory. It may also be worth exploring a potential role of other immunosuppressive cytokines such as IL-27 and IL-35.

\section{IMMUNE PARADOX AND PERIPHERAL ANERGY}

T-cell anergy is a term to describe hypo-responsiveness or incomplete activation of T-cells after exposure to common recall antigens, thought to be associated with a lack of adequate co-stimulation or overexposure to co-inhibitory signals (Crespo et al., 2013). In sarcoidosis, anergy is used to describe a lack of reaction to skin antigen tests (delayed type hypersensitivity) and ex vivo exposure to common recall antigens in peripheral blood (Mathew et al., 2008; Ahmadzai et al., 2012). This contrasts with the extensive local inflammation at sites of active disease and thus the phenomenon is also often referred to as an immune paradox (Miyara etal., 2006). Mechanisms of the observed sarcoid anergy are poorly understood and several theories have been proposed including compartmentalization of immune competent cells to the lung and, more recently, Treg, dendritic cells (DC), and T effector (Teff) cell dysfunction (Miyara et al., 2006; Mathew et al., 2008; Lee et al., 2011).

In fact it was initially hypothesized that the sarcoid peripheral anergy could be due to increased numbers of Treg cells that suppress proliferation of Teff cells (Miyara et al., 2006). Further studies confirmed that Treg cells are amplified in blood, BAL, and lymph node tissue of sarcoidosis patients, but these same studies indicate that these cells may in fact be impaired in their repressor function and might even contribute to pro-inflammatory granuloma formation (Taflin et al., 2009; Rappl et al., 2011; Oswald-Richter et al., 2013). Interestingly, disease resolution is associated with reversal of Th1 and Treg dysfunction (Oswald-Richter et al., 2013). Thus the original idea of Tregs contributing to peripheral anergy does not fully explain the phenomenon but nonetheless the cells seem to be dysregulated in sarcoidosis. Interestingly, peripheral blood and BAL sarcoid T-cells show selective hypersensitivity to 
possible sarcoid antigens while not only peripheral blood but also sarcoid BAL cells are hypo-responsive to common recall antigens (Ahmadzai et al., 2012; Oswald-Richter et al., 2013). It may be that instead of peripheral anergy, sarcoidosis is rather characterized by selective hypersensitivity to disease related antigens and hyporesponsiveness to common recall antigens. Further studies are required to compare the selective hypersensitivity and anergy in cells from BAL and peripheral blood. Likewise a role for immunosuppressive cytokines in the context of peripheral anergy in sarcoidosis should also be considered.

\section{IL-12 FAMILY CYTOKINES}

Whilst the pathogenesis of granuloma formation in sarcoidosis may be at odds with observed anergy in peripheral immune cells, one possible unifying factor may be the IL-12 family of cytokines. They are a unique group of heterodimeric cytokines composed of one of the three alpha subunits p19, p35, or p28 and one of the two beta subunits p40 or Epstein-Barr virus induced gene 3 (EBI3; Figure 2; Vignali and Kuchroo, 2012). p40 is the shared beta-subunit of IL-12 and IL-23, whereas IL-27 and IL-35 consist of the beta unit EBI3. The alpha subunit p19 is specific for IL-23 as is p28 for IL-27, whereas p35 is shared by IL-12 and IL-35. Similarly they bind to heterodimeric receptors and share five receptor subunits. Despite their common structures the biological function of the members of this family is very diverse (Figure 2). Whilst IL-12 and IL-23 are pro-inflammatory, IL-27 is bi-directional in terms of being both pro- and anti-inflammatory while IL-35 is strongly immunosuppressive (Vignali and Kuchroo, 2012).

\section{IL-12}

A role for IL-12 in sarcoid granuloma formation is well established (Figure 1; Iannuzzi and Fontana, 2011; Broos et al., 2013). Multiple studies confirm that IL-12p40 is elevated in blood, BAL, and granulomatous tissue from sarcoidosis patients and $\mathrm{PBMC}$ as well as BAL cells stimulated with sarcoid associated antigens produce higher amounts of IL-12 p40 in patients compared to healthy controls (Table 1). The corresponding IL-12 receptor chain IL$12 \mathrm{R} \beta 1$ is equally over-expressed in peripheral blood and BAL of sarcoidosis patients (Rogge et al., 1999; Taha et al., 1999; Judson et al., 2012). IL-12 is known to increase IFN $\gamma$ production and this holds true in sarcoid patients compared to controls (Shigehara et al., 2001). Recent studies suggest that Th17 cells may also produce IFN $\gamma$ in the presence of IL-12 (Annunziato et al., 2007; Boniface et al., 2010). IFN $\gamma$ has been shown to play a pivotal role in lung granuloma formation in murine models of tuberculosis (Cooper et al., 1997). It is thus likely that IL-12 (through promoting IFN $\gamma$ ) is of similar importance in sarcoidosis granuloma formation.

\section{IL-23}

IL-23 promotes the expansion and survival of Th17 cells, which have recently been linked to sarcoid granuloma formation (Figure 1; Broos et al., 2013). Gene analyses have revealed

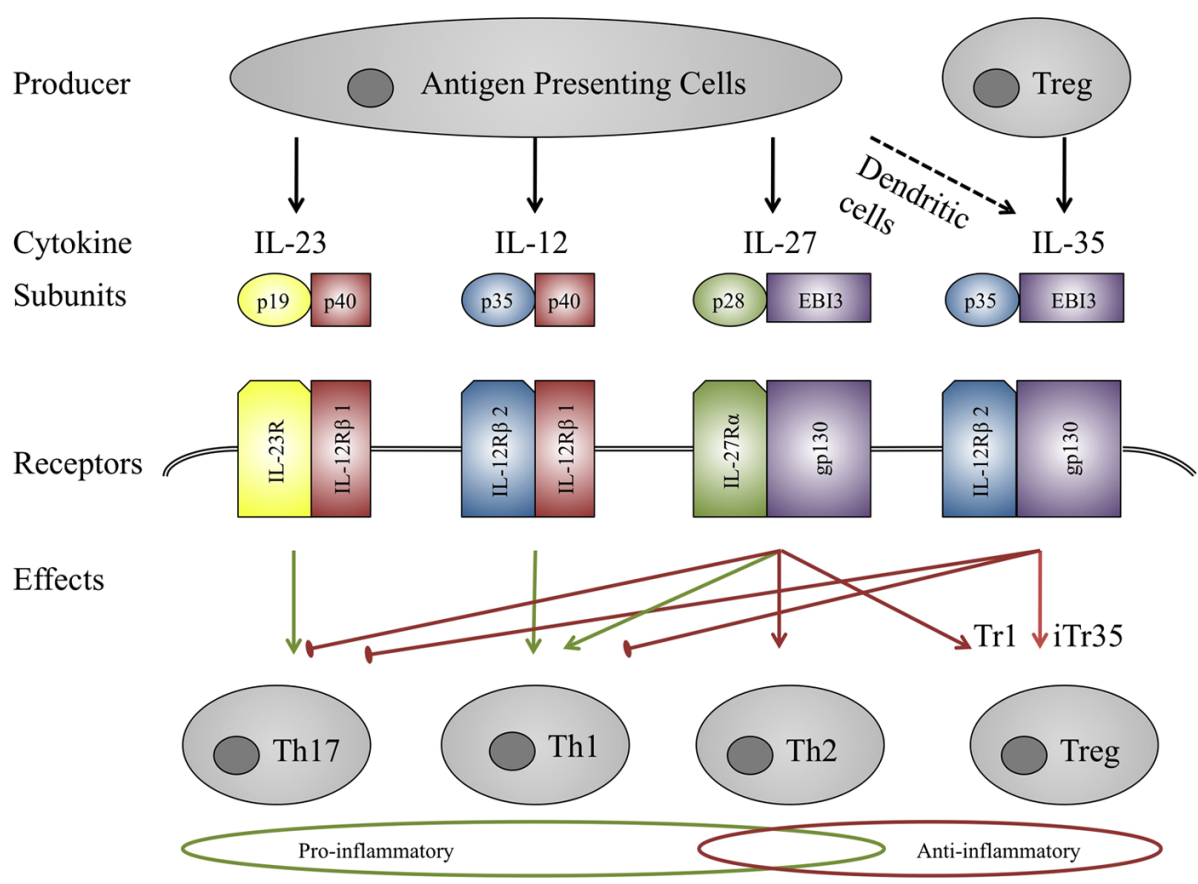

FIGURE 2 | IL-12 family members. IL-12 family members are heterodimers sharing three $\alpha$-chains (p35, p19, p28) and two $\beta$-chains (p40, EBI3). Similarly the receptors also consist of heterodimers. Signaling is mediated by the Jak-STAT family and affects different T-eff cell subsets. IL-23 and IL-12 act mainly pro-inflammatory through the activation of Th17 and Th1 cells, IL-27 seems to act in a pro-inflammatory manner on naïve T-cells and as an anti-inflammatory mediator on T-eff cells. IL-35 is immunosuppressive, inducing iTr35 cells. Green arrows indicate pro-inflammatory effects, red arrows represent anti-inflammatory properties. 
Table 1 | Studies on IL-12 and IL-12 receptors in sarcoidosis.

\begin{tabular}{|c|c|c|c|}
\hline \multicolumn{4}{|l|}{ Peripheral blood: } \\
\hline Method & & Result & Reference \\
\hline ELISA & & IL-12 p40 increased, IL-12p70 not detected (ELISA). & $\begin{array}{l}\text { Shigehara et al. (2003), } \\
\text { Hata et al. (2007) }\end{array}$ \\
\hline Antibody detection & & IL-12R $\beta 2$ not detected. & Rogge et al. (1999) \\
\hline mRNA, rtPCR & & $\begin{array}{l}\mathrm{IL}-12 \mathrm{R} \beta 1 \text { is elevated compared to healthy controls, but IL-12R } \beta 2 \text { is } \\
\text { not. }\end{array}$ & Judson et al. (2012) \\
\hline \multicolumn{4}{|l|}{ Granuloma lesions: } \\
\hline Affected organ & Method & Result & Reference \\
\hline Skin & mRNA, rtPCR & IL-12p40, IL-12R $\beta 1$ and IL-12R $\beta 2$ are elevated compared to controls. & Judson et al. (2012) \\
\hline Myocardium & IL12 ELISA and mRNA & $\begin{array}{l}\text { IL-12 is elevated (antibody not specified). IL-12p40 and IL-12p35 } \\
\text { mRNA are present but only IL } 12 \text { p40 significantly increased } \\
\text { compared to dilated cardiomyopathy controls. }\end{array}$ & Terasaki et al. (2008) \\
\hline Lymph node & mRNA, rtPCR & $\begin{array}{l}\text { IL-12p40 mRNA and IL-12R } \beta 2 \text { mRNA is elevated, but not IL12p35 or } \\
\text { IL-12R } \beta 1\end{array}$ & Hata et al. (2007) \\
\hline Lung and lymph node & Immunohistochemistry & IL-12p40 is expressed by epithelioid cells and macrophages. & Shigehara et al. (2003) \\
\hline Lymph node & mRNA & $\begin{array}{l}\text { IL-12p40 is significantly increased compared to controls but not } \\
\text { IL-12p35. }\end{array}$ & Bergeron et al. (1997) \\
\hline
\end{tabular}

\section{BAL:}

Method of detection

mRNA, ELISA

ELISA

Cytometric bead array

ELISA (not specified)

FISH mRNA detection

mRNA

Antibody detection

\section{Stimulation assays with sarcoid antigens}

Stimulus

\section{Cells}

Result

IL-12p40 mRNA and protein levels are significantly increased compared to healthy controls. BAL macrophages express higher levels of IL-12p70 both unstimulated and stimulated.

IL-12p40 is elevated compared to healthy controls, but not IL-12p70.

IL12p70 levels are significantly higher in patients compared to healthy controls.

IL-12 (not specified) is elevated compared to healthy controls.

P. acnes PBMC

$\beta$-glucan/LPS PBMC

NOD1/TLR4 ligands BALF
IL-12p40 significantly elevated in patients with active sarcoidosis but not inactive sarcoidosis.

IL-12Rß1 and IL-12Rß2 levels are elevated in sarcoidosis patients. BAL cells of sarcoidosis patients express IL-12R 2 .

\section{Result}

IL-12p40 mRNA levels are significantly elevated in sarcoidosis patients compared to healthy controls.

Spontaneous and post-stimulation IL-12 protein levels are higher in patients compared to controls (IL 12 ELISA not further specified).

IL12/23 p40 protein and mRNA levels are increased compared to healthy controls.

\section{Reference}

Moller etal. (1996)

Shigehara et al. (2001),

Barbarin et al. (2003)

Idali et al. (2006)

Kim etal. (2000), Meloni etal. (2004), Antoniou et al. (2006), Mroz et al. (2008)

Minshall et al. (1997)

Taha et al. (1999)

Rogge etal. (1999)

\section{Reference}

Furusawa etal. (2012)

Rastogi etal. (2011)

Rastogi et al. (2011)

Multiple studies confirm IL-12p40 and IL-12RB 1 up-regulation in peripheral blood, BAL, and granulomatous tissue, while the corresponding IL-12p35 is not dysregulated and IL-12p70 (the functional IL-12 protein) in most studies not detectable. 
Table 2 | Recent findings on pro- and anti-inflammatory effects of recombinant IL-27 on human cells in ex vivo studies.

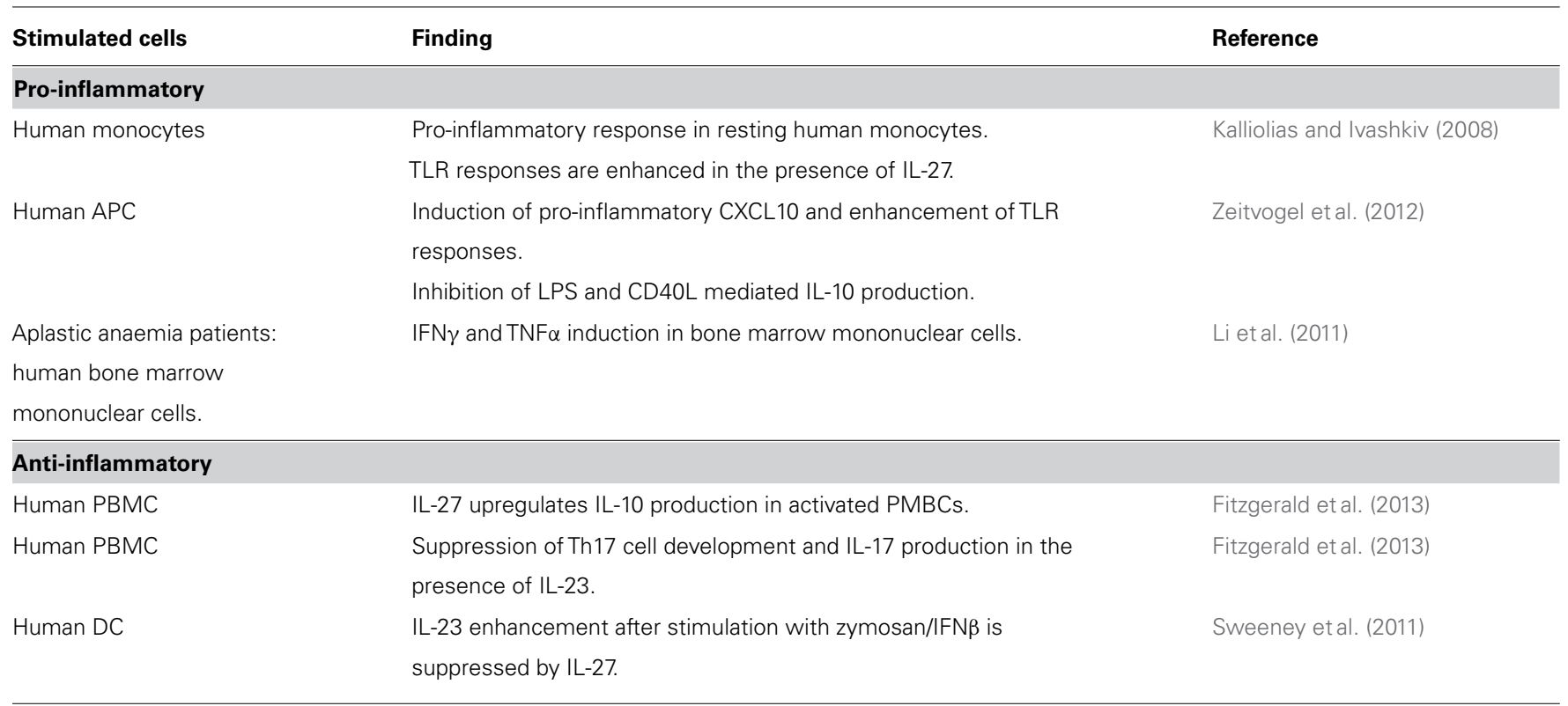

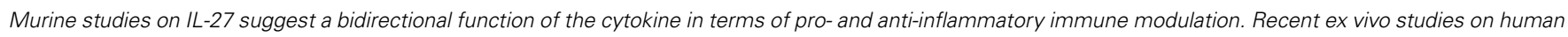
cells indicate that IL-27 might enhance inflammation in resting cells but inhibit immune responses in activated cells.

IL-23 receptor polymorphisms in sarcoidosis patients (Fischer et al., 2011; Kim et al., 2011). Furthermore IL-23 receptor mRNA is elevated in the granulomatous skin lesions of sarcoidosis patients and the same study also observed a trend for up-regulation of IL23 p19 in two thirds of sarcoid skin lesions, yet not in peripheral blood (Judson et al., 2012). Upon ex vivo stimulation with toll-like receptor 9 agonists, PBMCs of sarcoidosis patients produce less IL-23 compared to healthy controls suggesting that IL-23 might play a role in the formation of granulomas but not in peripheral blood (Veltkamp etal., 2010). Given the fact that IL-23 mostly acts as a pro-inflammatory cytokine through the promotion of Th17 development, these findings underline a possible role of Th17 cells in sarcoidosis. There is evidence that the Th17 cytokine IL-17A is required in granuloma formation following infection with mycobacteria (Fitzgerald et al., 2013). Since there are to date no murine models of sarcoidosis it is difficult to verify whether Th17/IL-17A contribution is essential in sarcoidosis as well. Yet IL-23 might promote IL-17A production by Th17 cells and thus contribute to pulmonary granuloma formation.

\section{IL-27}

Somewhat uniquely, IL-27 has been shown to have both proand anti-inflammatory effects (Table 2). Early studies focused on pro-inflammatory effects as IL-27 was shown to initiate clonal expansion of naïve T-cells and enhance INF $\gamma$ production together with IL-12 (Pflanz et al., 2002). It was also found to induce Th1 differentiation and showed pro-inflammatory effects on monocytes (Owaki et al., 2005, 2006; Kalliolias and Ivashkiv, 2008). In contrast to those findings, IL-27 receptor deficient mice that are infected with Toxoplasma gondii can still develop an immune response but are then unable to down-regulate that response, which ultimately proves to be fatal (Villarino et al., 2003). This suggests a pivotal role of IL-27 in immune modulation and one mechanism by which this is effected may be IL-10 induction in Th1, Th2, Th17, and Treg cells. These effects seem to be mediated via both the STAT1 and STAT3 proteins (Stumhofer et al., 2007). IL-27 also promotes IL-10 - producing regulatory type $1 \mathrm{~T}$-cells (Treg1) and can directly suppress Th17 cells (Apetoh et al., 2010; Sweeney et al., 2011; Fitzgerald et al., 2013). These results suggest a bidirectional function of IL-27, and while it seems to induce a pro-inflammatory response in naïve cells, the opposite is the case in activated cells (Kalliolias and Ivashkiv, 2008; Fitzgerald et al., 2013).

IL-27 and STAT3 were not dysregulated in sarcoid skin granulomas whereas STAT1 and STAT3 mRNA levels were elevated in the peripheral blood of sarcoidosis patients compared to healthy controls, but another group detected co-expression of the IL-27 subunits EBI3 and p28 (Figure 2) in epithelioid and multinucleate granuloma cells in sarcoid lymph nodes, suggesting a role of IL-27 in granuloma formation or resolution (Larousserie et al., 2004; Judson et al., 2012). Interestingly IL-27R-/- mice produce less IFN $\gamma$ at sites of granuloma formation in tuberculosis mice models suggesting that IL-27 might similarly contribute to early stages of granuloma formation in sarcoidosis (Pearl et al., 2004). At the same time IL-27 inhibits the production of TNF- $\alpha$ and IL-12 in activated peritoneal macrophages, suggesting an IL-27-mediated regulation of inflammation directed by macrophages in a murine model of tuberculosis (Li et al., 2012). The cytokine has recently been shown to be chemotactic for human DC and to impair HLA Class I antigen presentation in those cells (Morandi et al., 2014) and as the latter is believed to cause granuloma formation, IL-27 might thus also alter antigen presentation in sarcoidosis. IL-27 is a promising candidate for immune regulation in sarcoidosis but further studies are required to confirm IL-27 dysregulation 
in sarcoid tissue, analyse IL-27 expression in BALF and blood, and determine the effects of the cytokine in sarcoidosis and clarify whether it promotes inflammation and granuloma formation or contributes to disease clearance through its anti-inflammatory properties.

\section{IL-35}

IL-35 is the most recently identified member of the cytokine family. It seems to be mainly expressed upon stimulation and there is some evidence for human Treg cells as well as DC to be a source of this cytokine (Seyerl et al., 2010; Li et al., 2012; Guttek and Reinhold, 2013). IL-35 is so far believed to be strictly immunosuppressive, mediating regulatory $\mathrm{B}$ - and $\mathrm{T}$-cell function and increasing IL35 - induced regulatory T-cells which express IL-35 (iTr35), as well as inhibiting effector T-cell proliferation and Th17 development and function (Niedbala et al., 2007; Collison et al., 2010, 2012; Olson et al., 2013; Ye et al., 2013; Wang et al., 2014). There are only a few studies on the role of IL-35 in human diseases and disease models to date and unlike the other IL-12 family members there are currently no studies on IL-35 in sarcoidosis. In murine models of airway inflammation, IL-35 suppressed airway hyperresponsiveness via IL-17 suppression and is elevated in BAL upon treatment with erythromycin suggesting a role for IL-35 in ameliorating airway inflammation (Bai et al., 2012; Whitehead et al., 2012). Similarly transfer of iTr35 as well as Treg cells can cure experimental inflammatory bowel disease in mice, but not if those Treg cells lack either p35 or EBI3 (Collison et al., 2007, 2010). Sarcoidosis often presents as airway inflammation and non-caseating granulomas are a feature shared with Crohn's disease, an inflammatory bowel disease. Since Treg cell dysfunction and Th17 cells have also recently been linked to the pathogenesis of sarcoidosis IL-35 is an interesting target for further research in sarcoidosis that might contribute to disease clearance or the observed peripheral anergy.

\section{CONCLUSION AND PERSPECTIVES}

The etiology and pathogenesis of sarcoidosis remain enigmatic. Current concepts assume that the disease is caused by exposure to disease related antigens in genetically susceptible individuals. Although sarcoidosis was initially believed to be a Th1/IL-12/IFN $\gamma$ mediated disease, more recent advances have also revealed a contribution of pro-inflammatory IL-23 and Th17 cells in granuloma formation. But little is known about IL-12 family members and their possible role in fibrosis development or peripheral anergy. Whilst both IL-12 and IL-23 seem to be crucial proinflammatory players in granuloma formation, the only randomized controlled trial to date does not show efficacy of IL-12 and IL-23 blockade with ustekinumab in sarcoidosis (Judson et al., 2014). Given the fact that IL-12 enhances IFN $\gamma$ which then promotes granuloma formation the monoclonal IFN $\gamma$ antibody fontolizumab is another promising drug in the treatment of sarcoidosis showing some effects in phase 2 clinical trials in Crohn's disease (Hommes et al., 2006). The bidirectional IL-27 has also been detected in granulomas but further studies are required in order to determine whether it enhances inflammation or downregulates the excessive immune response at sites of inflammation.
However, since both IL-35 and IL-27 also have immunosuppressive properties further studies on a potential contribution to disease remission of these immunosuppressive cytokines could shed more light on the pathogenesis of sarcoid-related fibrosis and anergy. A clearer immunosuppressive function may indicate a role for stimulation of these cytokine and their receptors in the treatment of sarcoidosis and they could also be potential diagnostic markers for the disease.

\section{REFERENCES}

Acosta-Rodriguez, E. V., Napolitani, G., Lanzavecchia, A., and Sallusto, F. (2007). Interleukins lbeta and 6 but not transforming growth factor-beta are essential for the differentiation of interleukin 17-producing human T helper cells. Nat. Immunol. 8, 942-949. doi: 10.1038/ni1496

Adrianto, I., Lin, C. P., Hale, J. J., Levin, A. M., Datta, I., Parker, R., et al. (2012). Genome-wide association study of African and European Americans implicates multiple shared and ethnic specific loci in sarcoidosis susceptibility. PLoS ONE 7:e43907. doi: 10.1371/journal.pone.0043907

Ahmadzai, H., Cameron, B, Chui, J. J., Lloyd, A., Wakefield, D., and Thomas, P. S. (2012). Peripheral blood responses to specific antigens and CD28 in sarcoidosis. Respir. Med. 106, 701-709. doi: 10.1016/j.rmed.2012.01.012

Annunziato, F., Cosmi, L., Santarlasci, V., Maggi, L., Liotta, F., Mazzinghi, B., et al. (2007). Phenotypic and functional features of human Th17 cells. J. Exp. Med. 204, 1849-1861. doi: 10.1084/jem.20070663

Antoniou, K. M., Tzouvelekis, A., Alexandrakis, M. G., Tsiligianni, I., Tzanakis, N., Sfiridaki, K., et al. (2006). Upregulation of Th1 cytokine profile (IL-12, IL-18) in bronchoalveolar lavage fluid in patients with pulmonary sarcoidosis. J. Interferon Cytokine Res. 26, 400-405. doi: 10.1089/jir.2006.26.400

Apetoh, L., Quintana, F. J., Pot, C., Joller, N., Xiao, S., Kumar, D., et al. (2010). The aryl hydrocarbon receptor interacts with c-Maf to promote the differentiation of type 1 regulatory T cells induced by IL-27. Nat. Immunol. 11, 854-861. doi: 10.1038/ni.1912

Bai, J., Qiu, S. L., Zhong, X. N., Huang, Q. P., He, Z. Y., Zhang, J. Q., et al. (2012). Erythromycin enhances $\mathrm{CD} 4+$ Foxp3 + regulatory T-cell responses in a rat model of smoke-induced lung inflammation. Mediators Inflamm. 2012, 410232. doi: $10.1155 / 2012 / 410232$

Barbarin, V., Petrek, M., Kolek, V., Van Snick, J., Huaux, F., and Lison, D. (2003). Characterization of p40 and IL-10 in the BALF of patients with pulmonary sarcoidosis. J. Interferon Cytokine Res. 23, 449-456. doi: 10.1089/107969003322277865

Bargagli, E., Magi, B., Olivieri, C., Bianchi, N., Landi, C., and Rottoli, P. (2011). Analysis of serum amyloid a in sarcoidosis patients. Respir. Med. 105, 775-780. doi: 10.1016/j.rmed.2010.12.010

Bedoya, S. K., Lam, B., Lau, K., and Larkin, J. III, (2013). Th17 cells in immunity and autoimmunity. Clin. Dev. Immunol. 2013, 986789. doi: 10.1155/2013/986789 Bergeron, A., Bonay, M., Kambouchner, M., Lecossier, D., Riquet, M., Soler, P., et al. (1997). Cytokine patterns in tuberculous and sarcoid granulomas: correlations with histopathologic features of the granulomatous response. J. Immunol. 159, 3034-3043.

Boeck, C. (1899). Multipelt Benignt Hud-Sarkoid. Kristiania (Oslo): Steen'ske bogtrykkeri.

Boniface, K., Blumenschein, W. M., Brovont-Porth, K., McGeachy, M. J., Basham, B., Desai, B., etal. (2010). Human Th17 cells comprise heterogeneous subsets including IFN- $\gamma$-producing cells with distinct properties from the Th1 lineage. J. Immunol. 185, 679-687. doi: 10.4049/jimmunol. 1000366

Broos, C. E., van Nimwegen, M., Hoogsteden, H. C., Hendriks, R. W., Kool, M., and van den Blink, B. (2013). Granuloma formation in pulmonary sarcoidosis. Front. Immunol. 4:437. doi: 10.3389/fimmu.2013.00437

Burke, W. M., Keogh, A., Maloney, P. J., Delprado, W., Bryant, D. H., and Spratt, P. (1990). Transmission of sarcoidosis via cardiac transplantation. Lancet 336, 1579. doi: 10.1016/0140-6736(90)93354-R

Chen, E. S., and Moller, D. R. (2011). Sarcoidosis-scientific progress and clinical challenges. Nat. Rev. Rheumatol. 7, 457-467. doi: 10.1038/nrrheum.2011.93

Chen, E. S., Song, Z., Willett, M. H., Heine, S., Yung, R. C., Liu, M. C., et al. (2010). Serum amyloid a regulates granulomatous inflammation in sarcoidosis 
through Toll-like receptor-2. Am. Respir. Crit. Care Med. 181, 360-371. doi: 10.1164/rccm.200905-0696OC

Co, D. O., Hogan, L. H., Il-Kim, S., and Sandor, M. (2004). T cell contributions to the different phases of granuloma formation. Immunol. Lett. 92, 135-142. doi: 10.1016/j.imlet.2003.11.023

Collison, L. W., Chaturvedi, V., Henderson, A. L., Giacomin, P. R., Guy, C., Bankoti, J., et al. (2010). IL-35-mediated induction of a potent regulatory $\mathrm{T}$ cell population. Nat. Immunol. 11, 1093-1101. doi: 10.1038/ ni. 1952

Collison, L. W., Delgoffe, G. M., Guy, C. S., Vignali, K. M., Chaturvedi, V., Fairweather, D., et al. (2012). The composition and signaling of the IL35 receptor are unconventional. Nat. Immunol. 13, 290-299. doi: 10.1038/ ni.2227

Collison, L. W., Workman, C. J., Kuo, T. T., Boyd, K., Wang, Y., Vignali, K. M., et al. (2007). The inhibitory cytokine IL-35 contributes to regulatory T-cell function. Nature 450, 566-569. doi: 10.1038/nature06306

Cooper, A. M., Magram, J., Ferrante, J., and Orme, I. M. (1997). Interleukin 12 (IL-12) is crucial to the development of protective immunity in mice intravenously infected with Mycobacterium tuberculosis. J. Exp. Med. 186, 39-45. doi: 10.1084/jem.186.1.39

Crespo, J., Sun, H., Welling, T. H., Tian, Z., and Zou, W. (2013). T cell anergy, exhaustion, senescence, and stemness in the tumor microenvironment. Curr. Opin. Immunol. 25, 214-221. doi: 10.1016/j.coi.2012.12.003

Daniil, Z., Mollaki, V., Malli, F., Koutsokera, A., Antoniou, K., Rodopoulou, P., et al. (2013). Polymorphisms and haplotypes in MyD88 are associated with the development of sarcoidosis: a candidate-gene association study. Mol. Biol. Rep. 40, 4281-4286. doi: 10.1007/s11033-013-2513-7

Das, B. B., Shoemaker, L., Kim, E., Mascio, C. E., and Austin, E. H. (2012). Severe calcification of the aorta (porcelain aorta) associated with sarcoidosis in a pediatric heart transplant recipient. Pediatric Transplant. 16, E162-E166. doi: 10.1111/j.1399-3046.2011.01557.x

Deubelbeiss, U., Gemperli, A., Schindler, C., Baty, F., and Brutsche, M. H. (2010). Prevalence of sarcoidosis in Switzerland is associated with environmental factors. Eur. Respir. J. 35, 1088-1097. doi: 10.1183/09031936. 00197808

Drake, W. P., Oswald-Richter, K., Richmond, B. W., Isom, J., Burke, V. E., Algood, H., et al. (2013). Oral antimycobacterial therapy in chronic cutaneous sarcoidosis: a randomized, single-masked, placebo-controlled study. J. Am. Acad. Dermatol. 149, 1040-1049. doi: 10.1001/jamadermatol.2013.4646

Dubaniewicz, A. (2013). Microbial and human heat shock proteins as 'danger signals' in sarcoidosis. Hum. Immunol. 74, 1550-1558. doi: 10.1016/j.humimm.2013.08.275

Dubaniewicz, A., Holownia, A., Kalinowski, L., Wybieralska, M., Dobrucki, I. T., and Singh, M. (2013). Is mycobacterial heat shock protein $16 \mathrm{kDa}$, a marker of the dormant stage of Mycobacterium tuberculosis, a sarcoid antigen? Hum. Immunol. 74, 45-51. doi: 10.1016/j.humimm.2012.10.007

Eishi, Y. (2013). Etiologic link between sarcoidosis and Propionibacterium acnes. Respir. Investig. 51, 56-68. doi: 10.1016/j.resinv.2013. 01.001

Erdal, B. S., Clymer, B. D., Yildiz, V. O., Julian, M. W., and Crouser, E. D. (2012). Unexpectedly high prevalence of sarcoidosis in a representative US Metropolitan population. Respir. Med. 106, 893-899. doi: 10.1016/j.rmed.2012. 02.007

Facco, M., Cabrelle, A., Teramo, A., Olivieri, V., Gnoato, M., Teolato, S., et al. (2011). Sarcoidosis is a Th1/Th17 multisystem disorder. Thorax 66, 144-150. doi: 10.1136/thx.2010.140319

Fischer, A., Nothnagel, M., Franke, A., Jacobs, G., Saadati, H. R., Gaede, K. I., et al. (2011). Association of inflammatory bowel disease risk loci with sarcoidosis, and its acute and chronic subphenotypes. Eur. Respir. J. 37, 610-616. doi: 10.1183/09031936.00049410

Fitzgerald, D. C., Fonseca-Kelly, Z., Cullimore, M. L., Safabakhsh, P., Saris, C. J., Zhang, G. X., et al. (2013). Independent and interdependent immunoregulatory effects of IL-27, IFN- $\beta$, and IL-10 in the suppression of human Th17 cells and murine experimental autoimmune encephalomyelitis. J. Immunol. 190, 3225 3234. doi: 10.4049/jimmunol.1200141

Furusawa, H., Suzuki, Y., Miyazaki, Y., Inase, N., and Eishi, Y. (2012). Th1 and Th17 immune responses to viable Propionibacterium acnes in patients with sarcoidosis. Respir. Investig. 50, 104-109. doi: 10.1016/j.resinv.2012. 07.001
Grubic, Z., Peros-Golubicic, T., Stingl, K., and Zunec, R. (2011). The investigation of HLA microsatellites influence in predisposition to sarcoidosis among Croatians. Sarcoidosis Vasc. Diffuse Lung Dis. 28, 18-26.

Grunewald, J., Brynedal, B., Darlington, P., Nisell, M., Cederlund, K., Hillert, J., etal. (2010). Different HLA-DRB1 allele distributions in distinct clinical subgroups of sarcoidosis patients. Respir. Res. 11, 25. doi: 10.1186/14659921-11-25

Gupta, D., Agarwal, R., Aggarwal, A. N., and Jindal, S. K. (2007). Molecular evidence for the role of mycobacteria in sarcoidosis: a meta-analysis. Eur. Respir. J. 30, 508-516. doi: 10.1183/09031936. 00002607

Guttek, K., and Reinhold, D. (2013). Stimulated human peripheral $\mathrm{T}$ cells produce high amounts of IL-35 protein in a proliferationdependent manner. Cytokine 64, 46-50. doi: 10.1016/j.cyto.2013. 04.037

Hata, M., Sugisaki, K., Miyazaki, E., Kumamoto, T., and Tsuda, T. (2007). Circulating IL-12 p40 is increased in the patients with sarcoidosis, correlation with clinical markers. Int. Med. 46, 1387-1393. doi: 10.2169/internalmedicine. 46.6278

Heinle, R., and Chang, C. (2014). Diagnostic Criteria for Sarcoidosis. Autoimmun. Rev. 13, 383-387. doi: 10.1016/j.autrev.2014.01.035

Heyll, A., Meckenstock, G., Aul, C., Sohngen, D., Borchard, F., Hadding, U., et al. (1994). Possible transmission of sarcoidosis via allogeneic bone marrow transplantation. Bone Marrow Transplant. 14, 161-164.

Hofmann, S., Fischer, A., Nothnagel, M., Jacobs, G., Schmid, B., Wittig, M., et al. (2013). Genome-wide association analysis reveals 12q13. 3-q14. 1 as new risk locus for sarcoidosis. Eur. Respir. J. 41, 888-900. doi: 10.1183/09031936. 00033812

Hommes, D. W., Mikhajlova, T. L., Stoinov, S., Štimac, D., Vucelic, B., Lonovics, J., et al. (2006). Fontolizumab, a humanised anti-interferon $\gamma$ antibody, demonstrates safety and clinical activity in patients with moderate to severe Crohn's disease. Gut 55, 1131-1137. doi: 10.1136/gut.2005.0 79392

Iannuzzi, M. C., and Fontana, J. R. (2011). Sarcoidosis: clinical presentation, immunopathogenesis, and therapeutics. J. Am. Med. Assoc. 305, 391-399. doi: 10.1001/jama.2011.10

Iannuzzi, M. C., Rybicki, B. A., and Teirstein, A. S. (2007). Sarcoidosis. N. Engl. J. Med. 357, 2153-2165. doi: 10.1056/NEJMra071714

Idali, F., Wiken, M., Wahlström, J., Mellstedt, H., Eklund, A., Rabbani, H., et al. (2006). Reduced Th1 response in the lungs of HLA-DRB1* 0301 patients with pulmonary sarcoidosis. Eur. Respir. J. 27, 451-9. doi: 10.1183/09031936.06. 00067105

Ikonomopoulos, J., Gazouli, M., Dontas, I., Sechi, L., Lukas, J. C., Balaskas, C., et al. (2006). The infectivity of sarcoid clinical material and its bacterial content inoculated in CBA mice. In Vivo 20, 807-813.

Ikonomopoulos, J. A., Gorgoulis, V. G., Kastrinakis, N. G., Galanos, A. A., Karameris, A., and Kittas, C. (2000). Experimental inoculation of laboratory animals with samples collected from sarcoidal patients and molecular diagnostic evaluation of the results. In Vivo 14, 761-765.

Iwai, K., and Takahashi, S. (1976). Transmissibility of sarcoid-specific granulomas in the footpads of mice. Ann. N. Y. Acad. Sci. 278, 249-259. doi: 10.1111/j.17496632.1976.tb47036.x

Judson, M. A., Baughman, R. P., Costabel, U., Drent, M., Gibson, K. F., Raghu, G., et al. (2014). Safety and efficacy of ustekinumab or golimumab in patients with chronic sarcoidosis. Eur. Respir. J. doi: 10.1183/09031936.00000914 [Epub ahead of print].

Judson, M. A., Marchell, R. M., Mascelli, M., Piantone, A., Barnathan, E. S., Petty, K. J., et al. (2012). Molecular profiling and gene expression analysis in cutaneous sarcoidosis: the role of interleukin-12, interleukin-23, and the Thelper 17 pathway. J. Am. Acad. Dermatol. 66, 901-910. doi: 10.1016/j.jaad.2011. 06.017

Kalliolias, G. D., and Ivashkiv, L. B. (2008). IL-27 activates human monocytes via STAT1 and suppresses IL-10 production but the inflammatory functions of IL-27 are abrogated by TLRs and p38. J. Immunol. 180, 6325-6333. doi: 10.4049/jimmunol.180.9.6325

Kim, D. S., Jeon, Y. G., Shim, T. S., Lim, C. M., Lee, S. D., Koh, Y., et al. (2000). The value of interleukin-12 as an activity marker of pulmonary sarcoidosis. Sarcoidosis Vasc. Diffuse Lung Dis. 17, 271-276. 
Kim, H. S., Choi, D., Lim, L. L., Allada, G., Smith, J. R., Austin, C. R., et al. (2011). Association of interleukin 23 receptor gene with sarcoidosis. Dis. Mark. 31, 17-24. doi: 10.3233/DMA-2011-0796

Larousserie, F., Pflanz, S., Coulomb-L'Herminé, A., Brousse, N., Kastelein, R., and Devergne, O. (2004). Expression of IL-27 in human Th1associated granulomatous diseases. J. Pathol. 202, 164-171. doi: 10.1002/ path. 1508

Lee, N. S., Barber, L., Kanchwala, A., Childs, C. J., Kataria, Y. P., Judson, M. A. et al. (2011). Low levels of NF-кB/p65 mark anergic CD4+ T cells and correlate with disease severity in sarcoidosis. Clin. Vaccine Immunol. 18, 223-234. doi: 10.1128/CVI.00469-10

Li, J., Zhao, Q., Xing, W., Feng, J., Wu, H., Li, H., et al. (2011). Interleukin-27 enhances the production of tumour necrosis factoralpha and interferon-gamma by bone marrow $\mathrm{T}$ lymphocytes in aplastic anaemia. Br. J. Haematol. 153, 764-772. doi: 10.1111/j.1365-2141.2010. 08431.x

Li, X., Mai, J., Virtue, A., Yin, Y., Gong, R., Sha, X., et al. (2012). IL-35 is a novel responsive anti-inflammatory cytokine-a new system of categorizing anti-inflammatory cytokines. PLoS ONE 7:e33628. doi: 10.1371/journal.pone. 0033628

Loke, W. S. J., Herbert, C., and Thomas, P. S. (2013). Sarcoidosis: immunopathogenesis and immunological markers. Int. J. Chronic Dis. 2013, 13. doi: 10.1111/j.1440-1746.2011.06940.x

Manel, N., Unutmaz, D., and Littman, D. R. (2008). The differentiation of human $\mathrm{T}(\mathrm{H})-17$ cells requires transforming growth factor-beta and induction of the nuclear receptor RORgammat. Nat. Immunol. 9, 641-649. doi: 10.1038/ni.1610

Mathew, S., Bauer, K. L., Fischoeder, A., Bhardwaj, N., and Oliver, S. J. (2008). The anergic state in sarcoidosis is associated with diminished dendritic cell function. J. Immunol. 181, 746-755. doi: 10.4049/jimmunol.181.1.746

Meloni, F., Caporali, R., Marone Bianco, A., Paschetto, E., Morosini, M., Fietta, A. M., et al. (2004). BAL cytokine profile in different interstitial lung diseases: a focus on systemic sclerosis. Sarcoidosis Vasc. Diffuse Lung Dis. 21, 111-118.

Milman, N., Lisby, G., Friis, S., and Kemp, L. (2004). Prolonged culture for mycobacteria in mediastinal lymph nodes from patients with pulmonary sarcoidosis. A negative study. Sarcoidosis Vasc. Diffuse Lung Dis. 21, 25-28.

Milman, N., Svendsen, C. B., Nielsen, F. C., and van Overeem Hansen, T. (2011) The BTNL2 A allele variant is frequent in Danish patients with sarcoidosis. Clin. Respir. J. 5, 105-111. doi: 10.1111/j.1752-699X.2010.00206.x

Minshall, E. M., Tsicopoulos, A., Yasruel, Z., Wallaert, B., Akoum, H., Vorng, H., et al. (1997). Cytokine mRNA gene expression in active and nonactive pulmonary sarcoidosis. Eur. Respir. J. 10, 2034-2039. doi: 10.1183/09031936.97. 10092034

Mitchell, D. N., Rees, R. J., and Goswami, K. K. (1976). Transmissible agents from human sarcoid and Crohn's disease tissues. Lancet 2, 761-765. doi: 10.1016/S0140-6736(76)90599-7

Miyara, M., Amoura, Z., Parizot, C., Badoual, C., Dorgham, K., Trad, S., et al. (2006). The immune paradox of sarcoidosis and regulatory T cells. J. Exp. Med. 203, 359-370. doi: 10.1084/jem.20050648

Moller, D. R., Forman, J. D., Liu, M. C., Noble, P. W., Greenlee, B. M., Vyas, P., et al. (1996). Enhanced expression of IL-12 associated with Th1 cytokine profiles in active pulmonary sarcoidosis. J. Immunol. 156, 4952-4960.

Morais, A., Lima, B., Peixoto, M. J., Alves, H., Marques, A., and Delgado, L. (2012). BTNL2 gene polymorphism associations with susceptibility and phenotype expression in sarcoidosis. Respir. Med. 106, 1771-1777. doi: 10.1016/j.rmed.2012.08.009

Morandi, F., Di Carlo, E., Ferrone, S., Petretto, A., Pistoia, V., and Airoldi, I. (2014). IL-27 in human secondary lymphoid organs attracts myeloid dendritic cells and impairs HLA class I-restricted antigen presentation. J. Immunol. 192, 2634-2642. doi: 10.4049/jimmunol.1302656

Moseley, P. L., Hemken, C., Monick, M., Nugent, K., and Hunninghake, G. (1986). Interferon and growth factor activity for human lung fibroblasts. Release from bronchoalveolar cells from patients with active sarcoidosis. Chest J. 89, 657-662. doi: 10.1378/chest.89.5.657

Mroz, R. M., Korniluk, M., Stasiak-Barmuta, A., and Chyczewska, E. (2008). Increased levels of interleukin-12 and interleukin-18 in bronchoalveolar lavage fluid of patients with pulmonary sarcoidosis. J. Physiol. Pharmacol. 59(Suppl. 6), $507-513$.
Müller-Quernheim, J., Prasse, A., and Zissel, G. (2012). Pathogenesis of sarcoidosis. Presse Med. 41, 275-287. doi: 10.1016/j.lpm.2012.03.018

Negi, M., Takemura, T., Guzman, J., Uchida, K., Furukawa, A., Suzuki, Y., et al. (2012). Localization of Propionibacterium acnes in granulomas supports a possible etiologic link between sarcoidosis and the bacterium. Mod. Pathol. 25, 1284-1297. doi: 10.1038/modpathol.2012.80

Newman, L. S., Rose, C. S., Bresnitz, E. A., Rossman, M. D., Barnard, J., Frederick, M., et al. (2004). A case control etiologic study of sarcoidosis: environmental and occupational risk factors. Am. J. Respir. Crit. Care Med. 170, 1324-1330. doi: 10.1164/rccm.200402-249OC

Nicholson, T., Plant, B., Henry, M., and Bredin, C. (2010). Sarcoidosis in Ireland: regional differences in prevalence and mortality from 1996-2005. Sarcoidosis Vasc. Diffuse Lung Dis. 27, 111-120.

Niedbala, W., Wei, X. Q., Cai, B., Hueber, A. J., Leung, B. P., McInnes, I. B., et al. (2007). IL-35 is a novel cytokine with therapeutic effects against collagen-induced arthritis through the expansion of regulatory $\mathrm{T}$ cells and suppression of Th17 cells. Eur. J. Immunol. 37, 3021-3029. doi: 10.1002/eji. 200737810

Olson, B. M., Sullivan, J. A., and Burlingham, W. J. (2013). Interleukin 35: a key mediator of suppression and the propagation of infectious tolerance. Front. Immunol. 4:315. doi: 10.3389/fimmu.2013.00315

Oswald-Richter, K. A., Beachboard, D. C., Seeley, E. H., Abraham, S., Shepherd, B. E., Jenkins, C. A., et al. (2012). Dual analysis for mycobacteria and propionibacteria in sarcoidosis BAL. J. Clin. Immunol. 32, 1129-1140. doi: 10.1007/s10875-0129700-5

Oswald-Richter, K. A., Culver, D. A., Hawkins, C., Hajizadeh, R., Abraham, S., Shepherd, B. E., et al. (2009). Cellular responses to mycobacterial antigens are present in bronchoalveolar lavage fluid used in the diagnosis of sarcoidosis. Infect. Immun. 77, 3740-3348. doi: 10.1128/IAI.00142-09

Oswald-Richter, K. A., Richmond, B. W., Braun, N. A., Isom, J., Abraham, S., Taylor, T. R., et al. (2013). Reversal of global CD4+ subset dysfunction is associated with spontaneous clinical resolution of pulmonary sarcoidosis. J. Immunol. 190, 5446-5453. doi: 10.4049/jimmunol.1202891

Owaki, T., Asakawa, M., Fukai, F., Mizuguchi, J., and Yoshimoto, T. (2006). IL-27 induces Th1 differentiation via p38 MAPK/T-bet-and intercellular adhesion molecule-1/LFA-1/ERK1/2-dependent pathways. J. Immunol. 177, 7579-7587. doi: 10.4049/jimmunol.177.11.7579

Owaki, T., Asakawa, M., Morishima, N., Hata, K., Fukai, F., Matsui, M., et al. (2005). A role for IL-27 in early regulation of Th1 differentiation. J. Immunol. 175, 2191-2200. doi: 10.4049/jimmunol.175.4.2191

Padilla, M. L., Schilero, G. J., and Teirstein, A. S. (2002). Donor-acquired sarcoidosis. Sarcoidosis Vasc. Diffuse Lung Dis. 19, 18-24.

Patterson, K. C., Franek, B. S., Muller-Quernheim, J., Sperling, A. I., Sweiss, N. J., and Niewold, T. B. (2013). Circulating cytokines in sarcoidosis: phenotypespecific alterations for fibrotic and non-fibrotic pulmonary disease. Cytokine 61, 906-911. doi: 10.1016/j.cyto.2012.12.016

Patterson, K. C., Hogarth, K., Husain, A. N., Sperling, A. I., and Niewold, T. B. (2012). The clinical and immunologic features of pulmonary fibrosis in sarcoidosis. Trans. Res. 160, 321-331. doi: 10.1016/j.trsl.2012.03.005

Pearl, J. E., Khader, S. A., Solache, A., Gilmartin, L., Ghilardi, N., and Cooper, A. M. (2004). IL-27 signaling compromises control of bacterial growth in mycobacteriainfected mice. J. Immunol. 173, 7490-7496. doi: 10.4049/jimmunol.173.12. 7490

Pflanz, S., Timans, J. C., Cheung, J., Rosales, R., Kanzler, H., Gilbert, J., et al. (2002). IL-27, a heterodimeric cytokine composed of EBI3 and p28 protein, induces proliferation of naive CD4+ T Cells. Immunity 16, 779-790. doi: 10.1016/S10747613(02)00324-2

Prasse, A., Georges, C., Biller, H., Hamm, H., Matthys, H., Luttmann, W., et al. (2000). Thl cytokine pattern in sarcoidosis is expressed by bronchoalveolar CD4+ and CD8+ T cells. Clin. Exp. Immunol. 122, 241-248. doi: 10.1046/j.1365-2249.2000.01365.x

Prasse, A., Pechkovsky, D. V., Toews, G. B., Jungraithmayr, W., Kollert, F., Goldmann, T., et al. (2006). A vicious circle of alveolar macrophages and fibroblasts perpetuates pulmonary fibrosis via CCL18. Am. J. Respir. Crit. Care Med. 173, 781-792. doi: 10.1164/rccm.200509-1518OC

Prokop, S., Heppner, F. L., Goebel, H. H., and Stenzel, W. (2011). M2 polarized macrophages and giant cells contribute to myofibrosis in neuromuscular sarcoidosis. Am. J. Pathol. 178, 1279-1286. doi: 10.1016/j.ajpath.2010.11.065 
Pukiat, S., McCarthy, P. L. Jr., Hahn, T., Morrison, C., Shanahan, T., Qiu, J., etal. (2011). Sarcoidosis-associated MHC Ags and the development of cutaneous and nodal granulomas following allogeneic hematopoietic cell transplant. Bone Marrow Transplant. 46, 1032-1034. doi: 10.1038/bmt. 2010.235

Rappl, G., Pabst, S., Riemann, D., Schmidt, A., Wickenhauser, C., Schutte, W., et al. (2011). Regulatory T cells with reduced repressor capacities are extensively amplified in pulmonary sarcoid lesions and sustain granuloma formation. Clin. Immunol. 140, 71-83. doi: 10.1016/j.clim.2011.03.015

Rastogi, R., Du, W., Ju, D., Pirockinaite, G., Liu, Y., Nunez, G., et al. (2011). Dysregulation of p38 and MKP-1 in response to NOD1/TLR4 stimulation in sarcoid bronchoalveolar cells. Am. J. Respir. Crit. Care Med. 183, 500-510. doi: 10.1164/rccm.201005-0792OC

Richmond, B. W., Ploetze, K., Isom, J., Chambers-Harris, I., Braun, N. A., Taylor, T., et al. (2013). Sarcoidosis Th17 cells are ESAT-6 antigen specific but demonstrate reduced IFN-gamma expression. J. Clin. Immunol. 33, 446-55. doi: 10.1007/s10875-012-9817-6

Robinson, B., McLemore, T. L., and Crystal, R. G. (1985). Gamma interferon is spontaneously released by alveolar macrophages and lung $\mathrm{T}$ lymphocytes in patients with pulmonary sarcoidosis. J. Clin. Investig. 75, 1488-1495. doi: 10.1172/JCI111852

Rogge, L., Papi, A., Presky, D. H., Biffi, M., Minetti, L. J., Miotto, D., et al. (1999). Antibodies to the IL-12 receptor beta 2 chain mark human Th1 but not Th2 cells in vitro and in vivo. J. Immunol. 162, 3926-3932.

Rybicki, B. A., and Iannuzzi, M. C., (eds). (2007). "Epidemiology of sarcoidosis: recent advances and future prospects," in Seminars in Respiratory and Critical Care Medicine (New York: Thieme Medical Publishers).

Rybicki, B. A., Iannuzzi, M. C., Frederick, M. M., Thompson, B. W., Rossman, M. D., Bresnitz, E. A., et al. (2001). Familial aggregation of sarcoidosis: a casecontrol etiologic study of sarcoidosis (ACCESS). Am. J. Respir. Crit. Care Med. 164, 2085-2091. doi: 10.1164/ajrccm.164.11.2106001

Salazar, A., Mana, J., Fiol, C., Hurtado, I., Argimon, J. M., Pujol, R. et al. (2000). Influence of serum amyloid a on the decrease of high density lipoprotein-cholesterol in active sarcoidosis. Atherosclerosis 152, 497-502. doi: 10.1016/S0021-9150(00)00368-3

Sato, H., Woodhead, F. A., Ahmad, T., Grutters, J. C., Spagnolo, P., van den Bosch, J. M., et al. (2010). Sarcoidosis HLA class II genotyping distinguishes differences of clinical phenotype across ethnic groups. Hum. Mol. Genet. 19, 4100-4111. doi: $10.1093 / \mathrm{hmg} / \mathrm{ddq} 325$

Seyerl, M., Kirchberger, S., Majdic, O., Seipelt, J., Jindra, C., Schrauf, C., et al. (2010). Human rhinoviruses induce IL-35-producing treg via induction of B7H1 (CD274) and sialoadhesin (CD169) on DC. Eur. J. Immunol. 40, 321-329. doi: 10.1002/eji.200939527

Shigehara, K., Shijubo, N., Ohmichi, M., Kamiguchi, K., Takahashi, R., MoritaIchimura, S., et al. (2003). Increased circulating interleukin-12 (IL-12) p40 in pulmonary sarcoidosis. Clin. Exp. Immunol. 132, 152-157. doi: 10.1046/j.13652249.2003.02105.x

Shigehara, K., Shijubo, N., Ohmichi, M., Takahashi, R., Kon, S., Okamura, H., et al. (2001). IL-12 and IL-18 are increased and stimulate IFN-gamma production in sarcoid lungs. J. Immunol. 166, 642-649. doi: 10.4049/jimmunol. 166.1.642

Song, G. G., Kim, J. H., and Lee, Y. H. (2014). Associations between TNF- $\alpha-308$ A/G and lymphotoxin- $\alpha+252 \mathrm{~A} / \mathrm{G}$ polymorphisms and susceptibility to sarcoidosis: a meta-analysis. Mol. Biol. Rep. 41, 259-267. doi: 10.1007/s11033-013-2859-x

Spagnolo, P., and Grunewald, J. (2013). Recent advances in the genetics of sarcoidosis. J. Med. Genet. 50, 290-297. doi: 10.1136/jmedgenet-2013-101532

Spagnolo, P., Sato, H., Grutters, J. C., Renzoni, E. A., Marshall, S. E., Ruven, H. J., et al. (2007). Analysis of BTNL2 genetic polymorphisms in British and Dutch patients with sarcoidosis. Tissue Antigens 70, 219-227. doi: 10.1111/j.13990039.2007.00879.x

Stoll, S., Jonuleit, H., Schmitt, E., Müller, G., Yamauchi, H., Kurimoto, M., et al. (1998). Production of functional IL-18 by different subtypes of murine and human dendritic cells (DC): DC-derived IL-18 enhances IL-12-dependent Th1 development. Eur. J. Immunol. 28, 3231-3239. doi: 10.1002/(SICI)15214141(199810)28:10<3231::AID-IMMU3231>3.0.CO;2-Q

Stumhofer, J. S., Silver, J. S., Laurence, A., Porrett, P. M., Harris, T. H., Turka, L. A., et al. (2007). Interleukins 27 and 6 induce STAT3-mediated T cell production of interleukin 10. Nat. Immunol. 8, 1363-1371. doi: 10.1038/ni1537
Suzuki, H., Ota, M., Meguro, A., Katsuyama, Y., Kawagoe, T., Ishihara, M., et al. (2012). Genetic characterization and susceptibility for sarcoidosis in Japanese patients: risk factors of BTNL2 gene polymorphisms and HLA class II alleles. Investig. Ophthalmolol. Vis. Sci. 53, 7109-7115. doi: 10.1167/iovs.1210491

Sweeney, C. M., Lonergan, R., Basdeo, S. A., Kinsella, K., Dungan, L. S., Higgins, S. C., et al. (2011). IL-27 mediates the response to IFN-beta therapy in multiple sclerosis patients by inhibiting Th17 cells. Brain Behav. Immun. 25, 1170-1181. doi: 10.1016/j.bbi.2011.03.007

Taflin, C., Miyara, M., Nochy, D., Valeyre, D., Naccache, J. M., Altare, F., et al. (2009). FoxP3 + regulatory T cells suppress early stages of granuloma formation but have little impact on sarcoidosis lesions. Am. J. Pathol. 174, 497-508. doi: 10.2353/ajpath.2009.080580

Taha, R. A., Minshall, E. M., Olivenstein, R., Ihaku, D., Wallaert, B., Tsicopoulos, A., et al. (1999). Increased expression of IL-12 receptor mRNA in active pulmonary tuberculosis and sarcoidosis. Am. J. Respir. Crit. Care Med. 160, 1119-1123. doi: 10.1164/ajrccm.160.4.9807120

Takemori, N., Nakamura, M., Kojima, M., and Eishi, Y. (2014). Successful treatment in a case of Propionibacterium acnes-associated sarcoidosis with clarithromycin administration: a case report. J. Med. Case Rep. 8, 15. doi: 10.1186/1752-19 47-8-15

Ten Berge, B., Paats, M. S., Bergen, I. M., van den Blink, B., Hoogsteden, H. C., Lambrecht, B. N., et al. (2012). Increased IL-17A expression in granulomas and in circulating memory $\mathrm{T}$ cells in sarcoidosis. Rheumatology (Oxford) 51, 37-46. doi: 10.1093/rheumatology/ker316

Terasaki, F., Ukimura, A., Tsukada, B., Fujita, S., Katashima, T., Otsuka, K., et al. (2008). Enhanced expression of type 1 helper T-cell cytokines in the myocardium of active cardiac sarcoidosis. Circ. J. 72, 1303-1307. doi: 10.1253/circj. 72.1303

Terčelj, M., Rott, T., and Rylander, R. (2007). Antifungal treatment in sarcoidosis-a pilot intervention trial. Respir. Med. 101, 774-778. doi: 10.1016/j.rmed.2006.08.005

Terčelj, M., Salobir, B., Zupancic, M., and Rylander, R. (2011a). Antifungal medication is efficient in the treatment of sarcoidosis. Ther. Adv. Respir. Dis. 5, 157-162. doi: 10.1177/1753465811401648

Terčelj, M., Salobir, B., Harlander, M., and Rylander, R. (2011b). Fungal exposure in homes of patients with sarcoidosis-an environmental exposure study. Environ. Health 10, 8. doi: 10.1186/1476-069X-10-8

Terčelj, M., Salobir, B., Zupancic, M., Wraber, B., and Rylander, R. (2013). Inflammatory markers and pulmonary granuloma infiltration in sarcoidosis. Respirology 19, 225-230. doi: 10.1111/resp.12199

Urbankowski, T., Hoser, G., and Domagala-Kulawik, J. (2012). Th1/Th2/Th17related cytokines in the bronchoalveolar lavage fluid of patients with sarcoidosis: association with smoking. Pol. Arch. Med. Wewn. 122, 320-325.

Vasakova, M., Sterclova, M., Kolesar, L., Slavcev, A., Skibova, J., and Striz, I. (2010). Cytokine gene polymorphisms in sarcoidosis. Sarcoidosis Vasc. Diffuse Lung Dis. 27, 70-75.

Veltkamp, M., Van Moorsel, C. H., Rijkers, G. T., Ruven, H. J., Van Den Bosch, J. M., and Grutters, J. C. (2010). Toll-like receptor (TLR)-9 genetics and function in sarcoidosis. Clin. Exp. Immunol. 162, 68-74. doi: 10.1111/j.1365-2249.2010. 04205.x

Veltkamp, M., Wijnen, P. A., van Moorsel, C. H., Rijkers, G. T., Ruven, H. J., Heron, M., et al. (2007). Linkage between toll-like receptor (TLR) 2 promotor and intron polymorphisms: functional effects and relevance to sarcoidosis. Clin. Exp. Immunol. 149, 453-462. doi: 10.1111/j.1365-2249.2007.03428.x

Vignali, D. A., and Kuchroo, V. K. (2012). IL-12 family cytokines: immunological playmakers. Nat. Immunol. 13, 722-728. doi: 10.1038/ni.2366

Villarino, A., Hibbert, L., Lieberman, L., Wilson, E., Mak, T., Yoshida, H., et al. (2003). The IL-27R (WSX-1) is required to suppress T cell hyperactivity during infection. Immunity 19, 645-655. doi: 10.1016/S1074-7613(03)00300-5

Volpe, E., Servant, N., Zollinger, R., Bogiatzi, S. I., Hupe, P., Barillot, E., et al. (2008). A critical function for transforming growth factor-beta, interleukin 23 and proinflammatory cytokines in driving and modulating human $\mathrm{T}(\mathrm{H})-17$ responses. Nat. Immunol. 9, 9650-9657. doi: 10.1038/ni.1613

Wahlstrom, J., Dengjel, J., Persson, B., Duyar, H., Rammensee, H. G., Stevanovic, S., et al. (2007). Identification of HLA-DR-bound peptides presented by human bronchoalveolar lavage cells in sarcoidosis. J. Clin. Investig. 117, 3576-3582. doi: 10.1172/JCI32401 
Wahlstrom, J., Dengjel, J., Winqvist, O., Targoff, I., Persson, B., Duyar, H., et al. (2009). Autoimmune $\mathrm{T}$ cell responses to antigenic peptides presented by bronchoalveolar lavage cell HLA-DR molecules in sarcoidosis. Clin. Immunol. 133, 353-363. doi: 10.1016/j.clim.2009. 08.008

Wang, R. X., Yu, C. R., Dambuza, I. M., Mahdi, R. M., Dolinska, M. B., Sergeev, Y. V., et al. (2014). Interleukin-35 induces regulatory B cells that suppress autoimmune disease. Nat. Med. 20, 633-641. doi: 10.1038/nm.3554

Wennerstrom, A., Pietinalho, A., Vauhkonen, H., Lahtela, L., Palikhe, A., Hedman, J., etal. (2012). HLA-DRB1 allele frequencies and C4 copy number variation in Finnish sarcoidosis patients and associations with disease prognosis. Hum. Immunol. 73, 93-100. doi: 10.1016/j.humimm.2011. 10.016

Whitehead, G. S., Wilson, R. H., Nakano, K., Burch, L. H., Nakano, H., and Cook, D. N. (2012). IL-35 production by inducible costimulator (ICOS)-positive regulatory $\mathrm{T}$ cells reverses established IL-17-dependent allergic airways disease. J. Allergy Clin. Immunol. 129, 207-15.e1-207-15.e5. doi: 10.1016/j.jaci.2011. 08.009

Wijnen, P. A., Cremers, J. P., Nelemans, P. J., Erckens, R. J., Hoitsma, E., Jansen, T. L., et al. (2014). Association of the TNF- $\alpha$ G-308A polymorphism with TNF-inhibitor response in sarcoidosis. Eur. Respir. J. 43, 1730-1739. doi: 10.1183/09031936.00169413

Wijnen, P. A., Nelemans, P. J., Verschakelen, J. A., Bekers, O., Voorter, C. E., and Drent, M. (2010). The role of tumor necrosis factor alpha G-308A polymorphisms in the course of pulmonary sarcoidosis. Tissue Antigens 75, 262-268. doi: 10.1111/j.1399-0039.2009.01437.x

Wijnen, P. A., Voorter, C. E., Nelemans, P. J., Verschakelen, J. A., and Bekers O., Drent, M. (2011). Butyrophilin-like 2 in pulmonary sarcoidosis: a factor for susceptibility and progression? Hum. Immunol. 72, 342-347. doi: 10.1016/j.humimm.2011.01.011

Wikén, M., Idali, F., Al Hayja, M. A., Grunewald, J., Eklund, A., and Wahlström, J. (2010). No evidence of altered alveolar macrophage polarization, but reduced expression of TLR2, in bronchoalveolar lavage cells in sarcoidosis. Respir. Res. 11, 121-133. doi: 10.1186/1465-992111-121

Wilson, N. J., Boniface, K., Chan, J. R., McKenzie, B. S., Blumenschein, W. M., Mattson, J. D., et al. (2007). Development, cytokine profile and function of human interleukin 17-producing helper T cells. Nat. Immunol. 8, 950-957. doi: $10.1038 /$ nil 497
Ye, S., Wu, J., Zhou, L., Lv, Z., Xie, H., and Zheng, S. (2013). Interleukin-35: the future of hyperimmune-related diseases? J. Interferon Cytokine Res. 33, 285-291. doi: 10.1089/jir.2012.0086

Yoshimoto, T., Takeda, K., Tanaka, T., Ohkusu, K., Kashiwamura, S., Okamura, H., et al. (1998). IL-12 up-regulates IL-18 receptor expression on T cells, Th1 cells, and B cells: synergism with IL-18 for IFN- $\gamma$ production. J. Immunol. 161, 3400-3407.

Zeitvogel, J., Werfel, T., and Wittmann, M. (2012). IL-27 acts as a priming signal for IL-23 but not IL-12 production on human antigenpresenting cells. Exp. Dermatol. 21, 426-430. doi: 10.1111/j.1600-0625.2012. 01484.x

Zhang, Y., Chen, X., Hu, Y., Du, S., Shen, L., He, Y., et al. (2013). Preliminary characterizations of a serum biomarker for sarcoidosis by comparative proteomic approach with tandem-mass spectrometry in ethnic Han Chinese patients. Respir. Res. 14, 18. doi: 10.1186/1465-9921-14-18

Zhou, Y., Shen, L., Zhang, Y., Jiang, D., and Li, H. (2011). Human leukocyte antigenA, -B, and -DRB1 alleles and sarcoidosis in Chinese Han subjects. Hum. Immunol. 72, 571-575. doi: 10.1016/j.humimm.2011.03.020

Zissel, G., Homolka, J., Schlaak, J., Schlaak, M., and Müller-Quernheim, J. (1996). Anti-inflammatory cytokine release by alveolar macrophages in pulmonary sarcoidosis. Am. J. Respir. Crit. Care Med. 154, 713-719. doi: 10.1164/ajrccm.154.3.8810610

Conflict of Interest Statement: The authors declare that the research was conducted in the absence of any commercial or financial relationships that could be construed as a potential conflict of interest.

Received: 04 August 2014; paper pending published: 11 September 2014; accepted: 03 October 2014; published online: 27 October 2014.

Citation: Ringkowski S, Thomas PS and Herbert C (2014) Interleukin-12 family cytokines and sarcoidosis. Front. Pharmacol. 5:233. doi: 10.3389/fphar.2014.00233

This article was submitted to Respiratory Pharmacology, a section of the journal Frontiers in Pharmacology.

Copyright (c) 2014 Ringkowski, Thomas and Herbert. This is an open-access article distributed under the terms of the Creative Commons Attribution License (CC BY).

The use, distribution or reproduction in other forums is permitted, provided the original author(s) or licensor are credited and that the original publication in this journal is cited, in accordance with accepted academic practice. No use, distribution or reproduction is permitted which does not comply with these terms. 